\begin{tabular}{|l|l|l||}
\hline \multicolumn{2}{|c|}{ PublisherInfo } \\
\hline \hline PublisherName & $:$ & BioMed Central \\
\hline \hline PublisherLocation & $:$ & London \\
\hline \hline PublisherImprintName & $:$ & BioMed Central \\
\hline \hline
\end{tabular}

\title{
What do Dictyosteliumand mammary gland have in common?
}

\begin{tabular}{||l|l|l||}
\hline \multicolumn{2}{|c|}{ ArticleInfo } \\
\hline \hline ArticleID & $:$ & 3771 \\
\hline \hline ArticleDOI & $:$ & $10.1186 /$ bcr-2001-68454 \\
\hline \hline ArticleCitationID & $:$ & 68454 \\
\hline \hline ArticleSequenceNumber & $:$ & 43 \\
\hline \hline ArticleCategory & $:$ & Paper Report \\
\hline \hline ArticleFirstPage & $:$ & 1 \\
\hline \hline ArticleLastPage & $:$ & 3 \\
\hline \hline & & RegistrationDate $\quad: \quad 2001-8-20$ \\
ArticleHistory & $:$ & Received \\
& Accepted $\quad$ 2001-5-9 \\
\hline \hline ArticleCopyright & $:$ & Biomed Central Ltd2001-8-20 \\
\hline \hline ArticleGrants & $:$ & \\
\hline \hline
\end{tabular}




\begin{tabular}{|l|l|l||}
\hline ArticleContext & $:$ & 1305833 \\
\hline
\end{tabular}

Karen L Schmeichel, ${ }^{\text {Aff1 }}$

Aff1 Lawrence Berkeley National Laboratory, Berkeley, CA, USA

\section{Keywords}

Collagen, extracellular matrix, gene targeting, lactation, mammary gland development, receptor tyrosine kinases

\section{Context}

The discoidin domain receptors, DDR1 and DDR2, display characteristics pertinent to the study of both extracellular matrix (ECM) and tyrosine-kinase-dependent intracellular signalling. DDR extracellular domains share homology with the Dictyostelium discoideumprotein discoidin, a lectin-like factor that is secreted by cells to form a primitive ECM during aggregation. In higher organisms, DDR1 and DDR2 function as receptors for collagen-rich substrates; ligation of collagens activates the tyrosine kinase domains intrinsic to the proteins. Thus DDRs mediate signalling events that are stimulated in response to cues from the ECM and are likely to be important determinants of cellular differentiation. This paper explores this hypothesis by examining the phenotypes of the DDR1-/- mouse.

\section{Significant findings}

Consistent with the detection of DDR1 binding sites in the uterine wall and in mammary glands during pregnancy, DDR $1^{-/-}$females exhibit defects in uterine blastocyst implantation and mammary gland function. DDR $1^{-/-}$females are lactationally impaired; although milk gene transcripts are expressed in the mammary epithelium, encoded proteins are not effectively produced and secreted into alveolar lumena. The authors attribute this defect to improper mammary gland development, citing delayed ductal outgrowth and ductal hyperproliferation as potential causes. Mammary epithelium from DDR1 ${ }^{-}$ '- mice shows increased collagen deposition. The authors conclude that, under normal circumstances, DDR1 negatively regulates two functions required for mammary gland function: epithelial proliferation and the synthesis of collagenous matrix components. On the basis of these observations, the authors suggest a role for DDR1 in human breast carcinoma progression. 


\section{Comments}

In the context of the mouse mammary gland, DDR1 plays a pivotal role in cell-matrix interactions that ultimately drive functional differentiation. Remarkably, the function of DDR1 parallels that of the distantly related Dictyostelium protein, discoidin, thereby underscoring the fundamental significance of cell-matrix interactions throughout evolution. DDR1 joins the ranks of other ECM receptors, such as integrins, that are well-established determinants of normal mammary gland function. DDR1 is particularly interesting given that it has the capacity not only to sense and respond to cues derived from extracellular substrata but also to participate in matrix remodeling. These findings pose a number of perplexing questions regarding DDR1 function during tumorigenesis. For example, how does the lack of DDR1 expression give rise to epithelial hyperproliferation in this mouse model while DDR1 overexpression is commonly observed in human breast tumors?

\section{Methods}

Alkaline phosphatase staining, histological and immunological staining, whole mount mammary gland analysis, western blotting, northern blotting, gene targeting

\section{Additional information}

\section{References}

1. Vogel WF, Aszodi A, Alves F, Pawson T: Discoidin domain receptor 1 tyrosine kinase has an essential role in mammary gland development. Mol Cell Biol . 2001, 21: 2906-2917. 